D

\title{
Alienation and the Sociology of Alfred Schutz
}

\author{
By JOAQUIN TRUJILLO
}

\begin{abstract}
This article investigates the phenomenon of alienation as its rendition relates to the sociology of Alfred Schutz. Its goal is to augment our understanding of alienation within the context of Schutz and hermeneuticphenomenology's interpretation of intersubjectivity. It responds to the question: "If the World is indeed so profoundly intersubjective", as Schutz's sociology and hermeneutic-phenomenology suggest, "why does the everyday person dwelling in the life-world of the natural attitude commonly not endure it?" This article begins with a review of Schutz's apparent neglect to address the phenomenon of alienation then responds to the capital question it poses with a hermeneutic-phenomenological exhibition of the matter that aims to compliment his sociology. Transcendental-horizonal and being-historical expositions of alienation are provided. The article concludes with a return to Schutz's sociology to determine whether it contains a hidden interpretation of alienation in light of the preceding analysis. The final section also tables considerations for further sociological and phenomenological research of alienation.
\end{abstract}

Keywords Alfred Schutz, alienation, intersubjectivity, sociology, phenomenology, hermeneutic-phenomenology.

This article investigates the phenomena it surmises are nucleating the

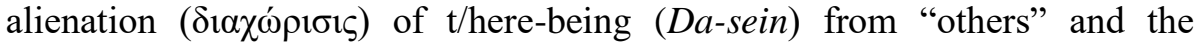
World ( $(\alpha \downarrow v o ́ \mu \varepsilon v o v)$ and freeing it to manifest in finite transcendence. It labors to expose the moments it posits are inducing the distancing-disjointing of t/here-being from itself and prompting it to appropriate the metaphysical dualisms of subjects and objects that have been found to commonly govern 
$\lambda$ ófos. The endeavor signifies a response to the capital question implied by, "Intersubjectivity and the Sociology of Alfred Schutz", ${ }^{1}$ the study anteceding this article that delivers a hermeneutic-phenomenological evaluation of Schutz's interpretation of intersubjectivity and propositionally augments it by way of a transcendental-horizonal and being-historical illumination of the phenomenon. The question the preceding article compels us to answer is this: "If the World is indeed a singularity that comprises each and every $t /$ herebeing transcending finitely in an unbroken continuity to the same $t /$ here and enowned (ereignetes) by the same 'is,' if t/here-being is indeed so profoundly intersubjective", as Schutz's sociology and hermeneutic-phenomenology suggest, "why does the everyday person dwelling in the life-world of the natural attitude (the everyday person $i s$ the life-world of the natural attitude) commonly not endure it?" Asked another way, "Why does the experience of the primal 'is-ness' of togetherness and the 'with' and 'in' of being commonly elude the common-sense person of the world of daily life?"

\section{Review of Part I}

The preceding study, part one of a two-part study, this article is the second part, deconstructs Schutz's interpretation of intersubjectivity into six general theses: (1) subjectivity is intersubjectivity, (2) intersubjectivity is a potentiality, (3) intersubjectivity is learned, (4) intersubjectivity is typical, (5) intersubjectivity is pragmatic, and (6) intersubjectivity is language. It endeavors to augment these assertions by situating them within Heidegger's rendition of the phenomenon, which it reduces to three moments within the course of thinking t/here-being (Da-sein) and be-ing (Ereignis, Seyn). The first moment is the elucidation of $\mathrm{t} / \mathrm{here-being}$ as being-with (Mitsein), beingwith-others (Mitdasein), and being-in-the-world (In-der-Welt-sein) that labors to bring to view the primordial "with" dimension of existence and the "is-ness" of togetherness. The second moment is the elucidation of the World as a singularity, as being-in-the-world. The third moment is the elucidation of t/here-being as language and the relation of language to Ereignis (enowning). It renders intersubjectivity from the hermeneutic-phenomenological theses, "human being is language" 2 and "we-human beings-are a conversation",

\footnotetext{
${ }^{1}$ Joaquin Trujillo, "Intersubjectivity and the Sociology of Alfred Schutz", Bulletin d'analyse phénoménologique 14, no 7 (2018).

2 George Kovacs, "Heidegger's Insight into the History of Language", Heidegger Studies 29 (2013), p. 129.
} 
and discerns enowning, the ownmost (essential) sway of the clearing of the self-concealing-withdrawing, of be-ing itself, underway in language. These moments, or, perhaps, better said, "joinings", as described in the preceding article and which, in the final analysis, do not belong to Heidegger, or anyone for that matter, but to the to-be-thought of the life-world and the equifinality $(\dot{\varepsilon} v \tau \varepsilon \lambda \dot{\varepsilon} \chi \varepsilon 1 \alpha)$ of thinking t/here-being and be-ing, show

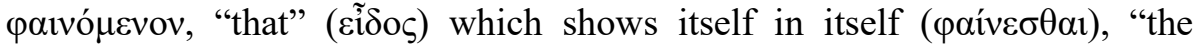
manifest", is exhaustively shared. T/here-beings together are, through-andthrough, being-with, being-with-others, and being-in-the-world. They indivisibly are, notwithstanding their individual uniqueness and finitude, the World. They inseparably are paivó $\mu \varepsilon v o v$ (the onefold, beings-in-the-whole), a totality (Total Meaningfulness) "that must be thought at all cost" if phenomenology is to bring it to view ${ }^{2}$. The hermeneutic-phenomenology of intersubjectivity reveals the "who" of Da-sein is "others" and the World.

The hermeneutic-phenomenology of intersubjectivity shows the lifeworld of the natural attitude to be far more intersubjective than Schutz's sociology reveals it to be, and renders the existential (ontological) basis of his imperative to assume from the outset the world of daily life is intersubjective. It goes beyond the thesis locating intersubjectivity within the stock of knowledge at hand by bringing to view the "with", as well as, by implication, the equally primordial "in", as Kalary and Schalow denote ${ }^{3}$, intrinsic to being, such that t/here-being is being-with, being-with-others, and being-in-the-world. It supersedes the correlation Schutz posits between intersubjectivity and "eminently practical" interests ${ }^{4}$ by revealing t/herebeing to be the thingness (being) of things. It supplants the fundamental correspondence Schutz posits between intersubjectivity and "the structure of language as a socially objectivated system of signs" and "we-relations" by showing t/here-being is language, language is enowned by be-ing, and

1 Martin Heidegger, "Hölderin and the Essence of Poetry", in Elucidations of Hölderlin's Poetry, ed. Keith Hoeller (Amherst: Humanity Books, 2000), p. 63.

${ }^{2}$ Parvis Emad, "On the Inception of Being-Historical Thinking and Its Unfolding as Mindfulness", Heidegger Studies 16 (2000), pp. 57-58.

${ }^{3}$ Thomas Kalary and Frank Schalow, "Attunement, Discourse, and the Onefold of Hermeneutic Phenomenology: Recent Heidegger-Literature and a New Translation of His Work in Critical Perspective", ibid.27 (2011), p. 202.

4 Alfred Schutz, "On Multiple Realities", Philosophy and Phenomenological Research 5, no. 4 (1945), p. 534.

${ }_{5}$ Alfred Schutz and Thomas Luckmann, The Structures of the Life-World, trans. Richard M. Zaner and Jr. H. Tristram Engelhardt, vol. 1 (Evanston: Northwestern University Press, 1995), p. 274. 
without language there would be no "is" and, hence, no being-with, no "other", and no World. It illumes the moments of "immediacy" and "vivid present" (other terms for being) Schutz says are the matter of the "tuning-in" that precedes a simultaneity of "streams of consciousness" and the "Werelationship". The hermeneutic-phenomenological analysis of Schutz's interpretation of intersubjectivity, the effort to augment it by way of transcendental-horizonally and being-historically thinking the phenomenon, suggests his sociology may be restraining its own empirical development by confining its hermeneutics to the investigation of the life-world of the natural attitude. It recommends it leverages its inherent openness to the existential analytic and propositionally assimilate transcendental-horizonal and beinghistorical theses about intersubjectivity to enhance its disclosing-saying power, guard itself against erroneous inferences ascribing it a dualistic (Cartesian) conception of human reality, and extend the horizons of its hermeneutical enterprise.

\section{Alienation and the world of daily life}

Schutz does not investigate the phenomenon of alienation. His sociology fails to address the matter, notwithstanding the phenomenon's capital importance to the structure and unfolding of subjectivity, social phenomena, culture, and the world of daily life. The neglect appears to be connected to the tendency of his sociology generally to elide the divergences (differences) among the subjective meanings embodied in (social) actions and their impact on the architecture and evolution of the life-world. The phenomenon of alienation, thought transcendental-phenomenologically, amounts to a divergence, often an oppositional one, between vónбıs and vó $\mu \alpha$. It is intentionality deviating from the self-givenness of its matter. Schutz's observations about divergence are confined largely to assertions unearthing the openness of typifications to their falsifiability, validation, and, hence, evolution ${ }^{2}$, the "contradicttions" endemic to the world of daily life, meaning, as Schutz writes, the life-world of the natural attitude is not "homogenous", "only partially clear", and large-

\footnotetext{
1 Schutz, "Making Music Together: A Study in Social Relationship", Social Research 18, no. 1 (1951), pp. 79, 89-90, 92, 95.

2 Alfred Schutz, "Language, Language Disturbances, and the Texture of Consciousness", Social Research 17, no. 3 (1950), p. 389; Aron Gurwitsch, "Introduction", in Collected Papers III: Studies in Phenomenological Philosophy, ed. I. Schutz (The Hague: Martinus Nijhoff, 1966), p. xvii.
} 
ly "incoherent", the uniqueness of the individual's stock of knowledge at hand, which he sources to the unique peculiarities, including spatiotemporal ones, of the biographically determined situation, the imposition of experiences, or "some of the elements of the world taken for granted", on the person that he must either avoid or endure ${ }^{2}$, and distinct systems of biographically articulated zones of relevance. "We have in common only a small section of our biographies", Schutz wrote in the notes Luckmann completed to write, The Structures of the Life-World, and "the other's system of relevance is founded in his unique biographical situation and thus cannot be congruent with mine", such that "it cannot be brought within my reach, although it can be understood by me" 3 .

The emphasis of Schutz's sociology is the exposition of socially produced, socially transmitted, open-ended patterns of meaning (typifications) that culturally manifest, shape, and embody the intersubjectivity he correctly asserts is immanent to the world of daily life. He strives to deliver a phenomenologically informed sociological framework to interpret the (typical) structure of the general similarities, congruencies, reciprocities, and adaptabilities of the meanings lived by everyday persons, those whom are "wide-awake", fully attentive to (absorbed in) their matter, and responding to the exigencies of everyday life. He begins his investigation of the life-world of the natural attitude from the pre-given understanding the world of daily life is intersubjective from its outset, moves to describing the commonsense standpoint of the everyday person, then proceeds to lay out its cultural constitution, including, as he writes, "the reciprocity of perspectives or the structural socialization of knowledge", "the social origin of knowledge", and "the social distribution of knowledge" 4 . He works to establish a framework for the scientific investigation of society, one that classifies social facts "under concepts in an honest and logical way", in contrast, for example, to the sociology of George Simmel, which he calls incontestably meaningful

\footnotetext{
${ }^{1}$ Alfred Schutz, "The Stranger: An Essay in Social Psychology", American Journal of Sociology 49, no. 6 (1944), p. 500.

2 "Choosing among Projects of Action", Philosophy and Phenomenological Research 12, no. 2 (1951), p. 168; "Tiresias, or Our Knowledge of Future Events", Social Research 26, no. 1 (1959), pp. 76, 83.

${ }^{3}$ Alfred Schutz and Thomas Luckmann, The Structures of the Life-World, trans. Richard M. Zaner and David J. Parent, vol. 2 (Evanston: Northwestern University Press, 1989), p. 256.

${ }^{4}$ Alfred Schutz, "Common-Sense and Scientific Interpretation of Human Action", Philosophy and Phenomenological Research 14, no. 1 (1953), pp. 4-7.
}

\section{5}


but methodologically "confused and unsystematic"1. In line with his general neglect of divergence, Schutz entirely ignores the discord endemic to the human situation, a phenomenon whose sociological relevance Simmel went to great lengths to describe and whose ownmost significance corresponds with the hermeneutical-phenomenological discernment of $\dot{\alpha} \lambda \dot{\eta} \theta \varepsilon t \alpha$ (be-ing), including the one Father William J. Richardson provides in his magmum opus, Heidegger: Through Phenomenology to Thought. There Richardson writes: " $\Lambda \eta \emptyset \eta$ ", the self-concealing-withdrawing, "not only is prior to $\dot{\alpha}$ $\lambda \eta \dot{\eta} \theta \varepsilon 1 \alpha "$, the clearing of $t /$ here, "but remains intrinsic to it at all times" such that being is "permeated with negativity"2. Heidegger's being-historical treatises further unfurls the meaning of this "negativity". "Errancy (Irre)", the inexhaustible struggle ingredient to $\dot{\alpha} \lambda \dot{\eta} \theta \varepsilon i \alpha$, to the open, turbulent dialogue between the $\alpha$-privativum and the verb, " $\lambda \eta \theta \omega$ ", is neither opposed to the truth nor removed from it; rather, it "is the appearing of truth itself in its own sway" as the self-clearing-concealing-sheltering ${ }^{3}$.

Simmel's rendition of conflict resonates with the opposition denoted by the being-historical elucidation of the interlocked, wrestling, cacophonic, back-and-forth dynamism ingredient to the unity of the privative and its opposite, to the ownmost sway of gifting-refusal hermeneutic-phenomenology has come to discern as enowning. It is the "play" in the enowned clearing of "time-play-space" and the meaning of the hyphen in " $\alpha-\lambda \eta \dot{\eta} \theta \varepsilon 1 \alpha$ "; the clearing of the self-concealing-sheltering "are not two [phenomena] but rather the essential swaying of the one, of truth itself" ${ }^{\prime 4}$. Conflict ( $\pi$ ó $\lambda \varepsilon \mu \circ \varsigma$, the struggleto-be) is ownmost to human being and intersubjectivity as such. It is ingredient to the life-world. It has a "sociologically positive character", as Simmel explains, and is "one of the most vivid interactions ["sociations"]". It resolves "divergent dualisms", and is a way of achieving "some kind of unity, even if it be through the annihilation of one of the conflicting parties". The person "does not attain the unity of his personality exclusively by an exhaustive harmonization", he adds, and "an absolutely centripetal and

${ }^{1}$ The Phenomenology of the Social World, trans. George Walsh and Frederick Lehnert (Evanston: Northwest University Press, 1967), p. 4.

${ }^{2}$ Richardson, Heidegger: Through Phenomenology to Thought, 2nd ed. (The Hague: Martinus Nijhoff, 1967), p. 492.

${ }^{3}$ Martin Heidegger, Mindfulness, trans. Parvis Emad and Thomas Kalary (London: Continuum International Publishing Group, 2006), p. 441.

${ }^{4}$ Contributions to Philosophy (from Enowning), trans. Parvis Emad and Kenneth Maly (Bloomington: Indiana University Press, 1999), p. 244. 
harmonious group, a pure 'unification' ('Vereinigung'), not only is empirically unreal, it could show no real life process"1.

Simmel's observations about conflict are noted here to throw into relief Schutz's disregard of divergence generally. Schutz's neglect of alienation, a basic form of divergence in the life-world, does not mean, however, his phenomenology cannot accommodate or support the phenomenon's investigation. It also does not mean Schutz did not recognize the transformative flux ingredient to biographically and socially produced situations. He did, and his interpretive framework of "because" and "inorder-to" motives ${ }^{2}$, for example, is fully capable of exhibiting within the parameters of his interpretive sociology divergences among subjectivities. The ability of Schutz's sociology to discern the phenomenon of alienation is exemplified in the writings of his students, Berger and Luckmann. They attribute their "redefinition" of the "sociology of knowledge", including their depiction of the social construction of reality as a dialectically produced outcome of the "externalization", "objectivation", and "internalization" of subjective meaning, principal elements of alienation (and reification) rendered phenomenologically, to Schutz's exposition of "the structure of the commonsense world of daily life" 3 . The understanding of alienation Berger and Pullberg deliver within their broader analysis of the phenomenon's role producing "the objectivity of social existence in its relatedness to human subjectivity" (i.e., persons "producing society" at the same time they are "produced by it") is also inspired by Schutz's thinking ${ }^{4}$. There they study alienation from the perspective "human subjectivity" is not a "closed sphere of interiority", but rather is "always intentionality in movement", and clarify it as "the process by which the unity of the producing and the product is broken". Alienation, according to Berger and Pullberg, signifies a radicalization of objectification. It is the moment wherein a person disconnects a human "producing and its product"-phenomena one has already objectified within/through consciousness so one can take "cognizance" of them-from its human genesis. It is integral to reification,

${ }^{1}$ George Simmel, Conflict and the Web of Group-Affiliations, trans. Kurt H. Wolff and Reinhard Bendix (New York: The Free Press, 1955), pp. 13-14.

${ }^{2}$ Schutz, The Phenomenology of the Social World, pp. 86-96; "Common-Sense and Scientific Interpretation of Human Action", pp. 16-20.

${ }^{3}$ Peter L. Berger and Thomas Luckmann, The Social Construction of Reality: A Treatise in the Sociology of Knowledge (New York: Doubleday, 1967), pp. 16-17, 20, 89.

${ }^{4}$ Peter L. Berger and Stanley Pullberg, "Reification and the Sociological Critique of Consciousness", History and Theory 4, no. 2 (1965), pp. 196-197. 
which Berger and Pullberg call, "objectification in an alienated mode," and describe as the moment in the process of alienation wherein a phenomenon consciousness has objectified becomes a "standard" of human reality ${ }^{1}$.

Although Schutz's sociology can readily accommodate the discovery of alienation in the world of daily life, it is not attuned to the phenomenon's more primordial meaning dimensions. Schutz's sociology signifies a new way of phenomenologically exhibiting human subjectivity, social phenomena, and the life-world of the natural attitude. It brings to view the intimacy between the social production and distribution of knowledge and the lifeworld of the wide-awake person. Schutz reveals the wide-awake person is the life-world of the natural attitude, a thesis that yields an array of possibilities for phenomenological exploration. Its general unsuitability to the investigation of the originary aspects of alienation comes from its orientation and syntax. The phenomenology through which Schutz works is more attuned to describing features of intentionality than it is to freeing the self-showing of meaning ownmost to human phenomena. When Schutz restricted his socio$\operatorname{logy}$ to the investigation of the life-world of the natural attitude after deeming unsuccessful Husserl's attempt to locate the constitution of intersubjectivity in the transcendental sphere ${ }^{2}$, he continued to appropriate the master's general phenomenological perspective. The decision was justifiable insofar as it enhanced the forensic precision of his work, which it did. It prescinded, however, broader, less sociologically oriented, although by no means sociologically insignificant, considerations of human existence. Schutz's sociology is more than capable of identifying and describing the alienation ensuing from the metaphysical dualisms common to the wideawake perspective and showing their unfurling in social phenomena, but, as it stands, is generally incapable of growing the understanding of the fundamental dimensions of human existence that may prompt the nucleation of alienation in transcendence. In much the same way Schutz's sociology does not contain the horizonal breadth to compel existentials (or be-ing) to show themselves from themselves as they are in themselves, as denoted in the preceding study, it does not have the capacity to wrest from hiddenness a deeper, although not exclusive, understanding of t/here-being's alienation from "others" and the World.

Schutz's syntax compounds the general inability of his sociology to differentiate the originary aspects of alienation. The language through which

\footnotetext{
${ }^{1}$ Ibid., pp. 199-200.

${ }^{2}$ Gurwitsch, "Introduction", pp. xiv-xv; Alfred Schutz, "The Problem of Transcendental Intersubjectivity in Husserl", ibid., p. 82.
} 
he works is not disposed toward unearthing the phenomenon's primal dimensions. It is held back by a divestiture of disclosing-saying power-the same deficiency that obstructs its ability to bring to view the with-structure of t/here-being, the "is-ness" of togetherness, and the singularity of the World - that ensues from its phenomenological vocabulary. Many of the terms Schutz commonly uses, such as "subject", "person", "actor", "alterego", "stream of consciousness", and "intersubjective", are Cartesian ones that tend to steer thinking toward an objectification of human phenomena, including alienation. (This assertion does not imply Schutz's thinking or sociology is governed by Cartesian dualisms. It only suggests his vocabulary is not suited to exhibiting the fundamental dimensions of the matter at hand: alienation.) Adding to the hidden obstacles Schutz's syntax may introduce into thinking human being and alienation, is his individuation of language as a system of "significative and symbolic relations" persons invent "to obtain knowledge of the world"1, storehouse of typifications and the "typifying medium par excellence by which social derived knowledge is transmitted"2, and vehicle of communication, as well as the correspondence he posits between language and "passive association". These theses connote an encapsulation of language that quashes the power of thinking to endure its equal primordiality with other existentials, such as being-with, being-withothers, and being-in-the-world, where the phenomenon of alienation is surmised to hold sway.

The balance of this article investigates the phenomenon of alienation hermeneutic-phenomenologically. It responds to the question begged in the preceding study and posed in the introduction: "Why does the 'wide-awake' person commonly fail to endure the profound intersubjectivity of the World?" The hermeneutic-phenomenology of alienation does not oppose the understanding Berger and Pullberg posit asserting the "anthropological" necessity of alienation - subjectivity embodying itself in processes and products available to persons "as elements of a common world" (objecttivation) and distancing itself from them (objectification) ${ }^{4}$ - to human living. It supports their thesis by illuming the matter's existential basis. It strives

\footnotetext{
1 "Symbol, Reality and Society", in Symbols and Society: Fourteenth Symposium on Science, Philosophy, and Religion, ed. Lyman Bryson, et al. (New York: Harper and Brothers, 1955), p. 142.

2 "Common-Sense and Scientific Interpretation of Human Action", p. 10.

3 "Symbol, Reality and Society", pp. 143-148, 165.

4 Berger and Pullberg, "Reification and the Sociological Critique of Consciousness", p. 201.
} 
also to augment the hermeneutics of intersubjectivity, including Schutz's, by bringing to view the ontological issuance of the distancing-disjointing t/herebeing commonly suffers between itself and "others" and itself and the World. It thinks (projects-open) alienation transcendental-horizonally, that is, from the elucidation of $t /$ here-being in relation to be-ing (enowning), and beinghistorically, the elucidation of be-ing in relation to $t /$ here-being. Transcendental-horizonal and being-historical perspectives do not signify different phenomenologies. Heidegger does not "discard" the first way to enact the second one, and there is no "break" between the two. They signify a "'back and forth' from one to the other", as Parvis Emad notes ${ }^{1}$. Beinghistorical thinking evolves from within the transcendental-horizonal perspective and ultimately returns back to its matter, to thinking the being-oft/here, albeit, with a difference: it endeavors also to show the surmised sway of be-ing in the World. Being-historical thinking is thinking enowning (Ereignisdenken) that opens the phenomenological attunement to the meaning of $\mathrm{t} /$ here-being and the way the truth of being (enowning), including the "counter sway of errancy" ingredient to be-ing ${ }^{2}$, clears the selfconcealing-withdrawing of beings-in-the-whole. It signifies a further radicalization of the phenomenology pioneered by Husserl, the one Being and Time undertook, to guard phenomenological thinking against "anthropological", "subjectivistic", "individualistic", and "substantialist" inferences and misreadings $\mathrm{s}^{3}$. Phenomenology is the grammar of being-in-the-world and be-ing, and the transcendental-horizonal and being-historical perspectives are part of one thesaurus. They are a single course projecting-opening (Entwerfen) the World and enowning's essential sway clearing the selfconcealing-withdrawing of t/here $(D a)$, the "lightening-clearing itself", as F.W. von Herrmann insightfully observes ${ }^{4}$, and letting the "phenomenon of disclosure" commandeer thinking5.

\footnotetext{
${ }^{1}$ Parvis Emad, On the Way to Heidegger's Contributions to Philosophy (Madison: University of Wisconsin Press, 2007), p. 200.

2 Frank Schalow, "Introduction", in Heidegger, Translation, and the Task of Thinking: Essays in Honor of Parvis Emad, ed. Frank Schalow, Contributions to Phenomenology (New York: Springer, 2011), p. 31.

3 Heidegger, Contributions to Philosophy (from Enowning), p. 208; Schalow, "Introduction", pp. 19, 28.

${ }^{4}$ Friedrich-Wilhelm von Herrmann, "Dasein and Da-Sein in Being and Time and in Contributions to Philosophy (from Enowning)", ibid., p. 221.

${ }^{5}$ George Kovacs, "The Idea of Hermeneutics in Heidegger", Existentia 10, no. 1-4 (2000), p. 41.
} 


\section{Alienation rendered transcendental-horizonally}

What is the understanding of alienation yielded by the transcendentalhorizonal perspective? Alienation is t/here-being rejecting, overlooking, ignoring, abandoning, or forgeting its ownmost, being-in-the-world, and

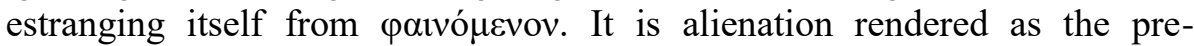

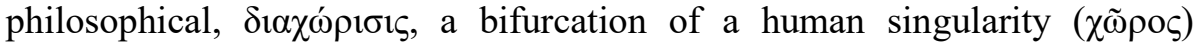
where the separated moments continue to belong to each other fundamentally and connote a hidden, unattended unity. It is like a divorce between a husband and wife. No matter how much time they may have been separated or dislike each other, no matter how irreconcilble their differences may be, there usually will always remain a deep familiarity between them that implies a certain, albeit fallow, mutual belongingness. Alienation, rendered transcendental-horizionally, sort of resonates with this significance. It is t/here-being meaningfully distanced or disjointed from "who" it is: "the disclosedness of being-in-the-world"1, and the beings, including other t/herebeings, illumed $t / h e r e$ with-in it. T/here-being is being-t/here-with-andamong-beings, including "others", factically and referentially (as factical possibilities). "Others", thought hermeneutic-phenomenologically, are not "alter-egos" intentionally constituted in a surmised transcendental sphere of pure subjectivity, as Husserl asserts in his "Fifth Meditation"2. They are primordially equal to t/here-being, characterized originarily by the "with" (mit), the "t/here" $(\mathrm{da})$, the "to-be" (sein), as well as the "concern for being" $(\text { Sorge })^{3}$. They, like t/here-being, are being-in-the-world, "others", and the concern for and comprehension of being (Verstehen). Being is an "issue" for them too, meaning, they finitely transcend beings to the being-of-t/here (they exist), and, like t/here-being, come-to-pass as the World ${ }^{4}$. They, with-t/herebeing, are the clearing of the self-concealing-withdrawing standing within the midst of beings (including other t/here-beings) and manifesting as beingsin-the-whole (das Seiende im Ganzen). They, with-t/here-being, are the being-of-t/here. T/here-being and "others" are the World showing itself as it is from itself: the singularity, paıvó $\mu \varepsilon v o v$. There is only one World, the

\footnotetext{
${ }^{1}$ Martin Heidegger, Being and Time, trans. John Macquarrie and Edward Robinson (New York: Harper \& Row, Publishers, 1962), p. 218.

${ }^{2}$ Edmund Husserl, "Fifth Meditation", in Cartesian Mediations: An Introduction to Phenomenology (Boston: Kluwer Academic Publishers, 1999).

${ }^{3}$ George Kovacs, The Question of God in Heidegger's Phenomenology (Evanston: Northwestern University Press, 1990), p. 73; Heidegger, Being and Time, pp. 154.

${ }^{4}$ Being and Time, pp. 32-35.
} 
manifest, and we are all inseparably unfurling as it ("that"). T/here-being's alienation from transcendence short-circuits the manifestation of the meaning of itself, of Da-sein, as the World and "others". It buries the "mit", " $d a$ ", "sein", and the "sorge" in its rejection or forgottenness of itself. The t/herebeing alienated from itself does not dispel these existentials. It does not eradicate them, no matter how much it may abscond or lose sight of itself. It is always-already them. The t/here-being who alienates itself from the facticity of its disclosedness suppresses these existentials by letting them lie fallow in concealment, in $\chi \alpha$ ós.

The transcendental-horizonal perspective, the hermeneutics of Da-sein in relation to Sein initiated in Being and Time, distinguishes three ways t/here-being alienates itself from transcendence. All of them nucleate from/within $\lambda$ ó $\gamma o s$, the disclosing-comprehending-saying power immanent to Da-sein, and the profound indigence of its radical finitude, that is: from its (1) fallenness (Verfallen), (2) the limitations endemic to its comprehension of being, and (3) the phenomenon of death. " $\Lambda$ ó $о$ os" is another name for "t/here-being". It is t/here-being distinguished as human finite transcending (human Da-sein); the profound indigence of t/here-being comes from it being

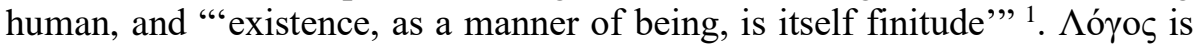
the discernment of $\mathrm{t} /$ here-being as human Da-sein. It is the unique being "to whom alone Da-sein fits" ${ }^{2}$. The disclosure of t/here-being as $\lambda$ ó ${ }^{\circ} \varsigma_{\text {s }}$ brings transcendence to view as a human, hence, finite, unfolding of disclosingcomprehending-saying and the being of beings-in-the-whole, the clearinggathering-comprehending ("letting-lie-forth") of the totality of things in their relatedness that frees it to emit (say, utter) its ownmost significance ${ }^{3}$. $\Lambda$ óyos is the hermeneutic-phenomenological equivalent of a "self", inasmuch as thinking t/here-being surmises one, a thesis Richardson also posits when he describes $\lambda$ ó $\gamma \circ \varsigma$ as the "gathering-point" of the disclosedness of $t /$ herebeing ${ }^{4}$. It encompasses the "mineness" of existence and the pre-philosophical

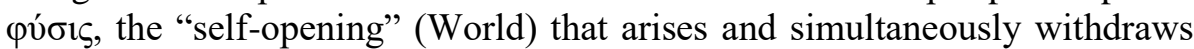

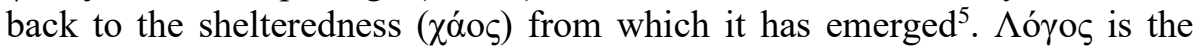

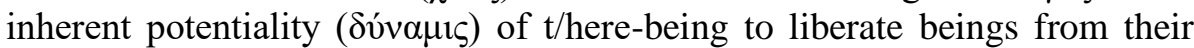
hiddenness, comprehend their being, and free their meaning to shine forth

\footnotetext{
${ }^{1}$ Richardson, Heidegger: Through Phenomenology to Thought, p. 38.

${ }^{2}$ Heidegger, Contributions to Philosophy (from Enowning), p. 212.

${ }^{3}$ Richardson, Heidegger: Through Phenomenology to Thought, pp. 490-501.

${ }^{4}$ Ibid., p. 494.

${ }^{5}$ Heidegger, "As When on a Holiday", p. 79; Mindfulness, p. 71; Contributions to Philosophy (from Enowning), p. 133.
} 
through words. Its interrogation unearths the equal-primordiality of t/here-

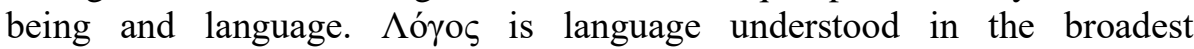
hermeneutic-phenomenological sense as discourse and $\lambda \dot{\varepsilon} \gamma \varepsilon i v$, or " "to-laybefore" "1. It lets the matter of discourse be seen by laying it in the open (the clearing) before the comprehension of being. It is the meaning of language revealed by the assertions: "human being is language" and "we-human beings-are a conversation". Encompassing the pre-philosophical understanding of pv́бıs, the hermeneutic-phenomenology of language includes the discernment of the meaning of the thingness of language, indeed, of the meaning of the thingness of things generally ${ }^{2}$, as an extension of the body and its power to transcend "signs," as Merleau-Ponty observes, and ground the meaning of $\mathrm{t} /$ here-being in phenomena and the World. ${ }^{3}$

a. Fallenness. The originary dependence of $\lambda$ óyos ( $t /$ here-being) on beings to be induces its fallenness, or being-fallen, one of three principal ways, clarified transcendentally-horizonally, alienation sways in finite transcendence. Fallenness denotes the inherent tendency of $\lambda$ ó $\gamma$ os to let itself be absorbed in beings and abscond the prerogative of its "to be". It is the "ineluctable drag" toward a comportment with beings $\mathrm{t} / \mathrm{here}$-being factically endures, encroaches on its comportment with being, and induces $\lambda$ ó $\gamma o \varsigma$ to forget its "to be". ${ }^{4}$ It includes (and irrupts from) a disavowal of its authenticity ( $\alpha \dot{v} \theta \varepsilon v \tau \imath \kappa o ́ \varsigma)$, or its potentiality to be aware, free, and responsible. Being-fallen, t/here-being's everyday mode of being, "drifts along an alienation [Entfremdung] in which its ownmost potentiality-for-being", its authenticity as such, "is hidden from it", Heidegger observes. ${ }^{5}$ T/here-being is thrown (geworfen) into the World (to be thrown is to have irrupted as factical disclosedness) gravitationally disposed towards its absorption in beings. It comes to be as the " downward plunge' [Absturz]" into beings ${ }^{6}$. It happens as the thingness of things, one whose spatiotemporal situatedness in the World is grounded in its ownmost thingness (the phenomenal body), and must meaningfully comport itself with beings to be. It needs beings to be, to live, to persevere, and to comprehend being: " $t /$ here-being's comprehending

${ }^{1}$ Richardson, Heidegger: Through Phenomenology to Thought, p. 491; Heidegger, Being and Time, p. 56.

${ }^{2}$ Martin Heidegger, "The Origin of the Work of Art", in Poetry, Language, Thought, ed. Albert Hofstadter (New York: Perennial Classics, 2001), pp. 25, 31.

3 Maurice Merleau-Ponty, Phenomenology of Perception, trans. Colin Smith (London: Routledge \& Kegan Paul, 1962), pp. 182-183.

${ }^{4}$ Richardson, Heidegger: Through Phenomenology to Thought, p. 38.

${ }^{5}$ Heidegger, Being and Time, pp. 222-223.

${ }^{6}$ Ibid., p. 223 
of being always comes-to-pass in and through its comportment with beings"1. It responds to its existentiality, its primeval task to be, the primordial "ought" of factical disclosedness, through an accord and struggle with things. It is predisposed toward forgoing attunement to transcendence and reifying itself in relation to things, to letting the comprehension of being drift into metaphysical dualisms individuating the World as an object populated by subjects (persons appropriated as beings devoid of transcendence) and objects.

Insofar as $\lambda$ ó $\gamma \circ \varsigma$ yields to its fallenness, it also tends to forgo itself as clearing. It loses sight of itself as being-with, being-with-others, and the World, and distances itself from the existentials. Its comprehension of being relinquishes itself to an impulse to calculate, control, and collect beings to preserve itself. It instrumentalizes beings, including other $\mathrm{t} / \mathrm{here}$-beings, to its compulsion to be. It disposes toward machinations. Its discourse leans toward technicity. It objectifies beings to put the "world" in order to support its own life. The (phenomenal) body must be fed and t/here-being must work to eat. T/here-being, a being whose "“ontic excellence'... lies in the fact that it is ontological,"” as Richardson writes ${ }^{2}$, requires shelter to be. It produces itself through labor, through creating, building, and arranging things. It is an abode dwelling being. It needs a home.

Fallenness includes the primordial impulse of $\lambda$ ó ${ }_{0} \varsigma \varsigma_{\text {to }}$ continue being. It entices $\lambda$ ó $\gamma \circ \varsigma$ with the promise of delivering a disposition of security and tranquility that "everything is 'in the best of order' and all the doors are open". It is a call that contains a specious invitation to master things ${ }^{3}$; essentially referred to beings, "hence referentially dependent upon them, it [t/here-being] can never become either by culture or by technicity completely

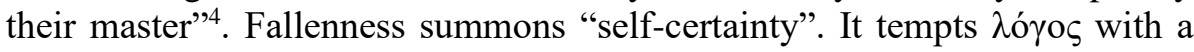
"guarantee...that all of the possibilities of its being will be secure, genuine, and full", thus drawing its ownmost into a mode where its comprehension of being is subjugated by the usability of things. T/here-being's dependence on beings to be foreordains $\lambda$ ó $\gamma$ o $\varsigma$ to a comportment with beings that obscures its comportment with being and alienates it from itself.

Fallenness does not signify a descent from a "purer and higher 'higher status," however. Characterizations like "downward" are phenomenal ones.

\footnotetext{
${ }^{1}$ Richardson, Heidegger: Through Phenomenology to Thought, p. 38.

${ }^{2}$ Ibid., p. 35; Heidegger, Being and Time, p. 32.

${ }^{3}$ Being and Time, p. 222.

${ }^{4}$ Richardson, Heidegger: Through Phenomenology to Thought, p. 37.

${ }^{5}$ Heidegger, Being and Time, p. 222.
} 
They are not valuations. Fallenness is the everyday mode of being of the factical t/here-being". It says "the propensity to forgetfulness" is as "inevitable and as abiding as everydayness itself" and "cannot be dissolved"2. Fallenness is a way $\lambda$ ó ${ }^{\circ} \varsigma$ commonly sways in transcendence. It is "the everyday of t/here-being lost in a forgotten-ness of itself" and "does not imply a negative value". It means, as Richardson thoughtfully writes:

t/here-being is 'first of all and for the most part' preoccupied with the 'World' of its ontic experience, $s c$., that totality of beings opposed to itself with which it is continuously engaged. And inevitably so. For it is bidimensional, ontic as well as ontological: it is only through an existentiell [ontic] engagement that the existential [ontological] prerogative can come-to-pass. If, however, t/herebeing is so absorbed in the ontic as to be oblivious to the ontological (being), it has forgotten the very prerogative that constitutes its uniqueness [the concern for and comprehension of being]; it has 'fallen from,' 'taken flight from' its authentic self, it is lost in inauthenticity (Uneigentlichkeit). Such is the condition of t/here-being 'first of all and for the most part' in the intercourse of every day ${ }^{3}$.

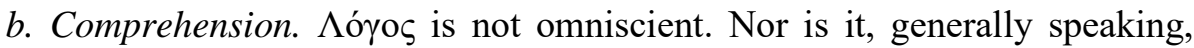
extraordinarily intelligent, no matter how much credit we tend to give ourselves as a species. It is the being-of-t/here, the World, yes, but it is not an all knowing, all seeing, all saying t/here-being. It factically is $\varphi \alpha$ ivó $\mu \varepsilon v o v$,

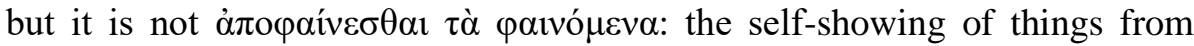

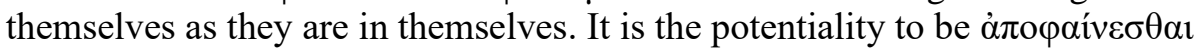
$\tau \grave{\text { }}$ palvó $\mu \varepsilon v \alpha$, a projecting-opening contingent on resolutely yielding awareness, with all the ups and downs, or "stumblings", as Heidegger writes in Contributions to Phenomenology ${ }^{4}$, intrinsic to that effort, to finite trans-

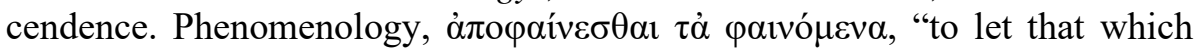
shows itself [beings-in-the-whole] be seen from itself in the very way in which it shows itself from itself', as rendered transcendental-horizionally in Being and Time ${ }^{5}$, is the possibility of $\lambda$ ó $\gamma$ o 5 coming to its ownmost inabiding (inständig) the being-of-t/here. It is not a certainty, and definitely not easy or common. It is to be striven for and a struggle to endure. It is a ceaseless, turbulent process, an endless underway pushing beyond the "boundaries of

\footnotetext{
${ }^{1}$ Ibid., pp. 219-221.

${ }^{2}$ Richardson, Heidegger: Through Phenomenology to Thought, p. 48.

${ }^{3}$ Ibid., p. 70.

${ }^{4}$ Heidegger, Contributions to Philosophy (from Enowning), p. 59.

${ }^{5}$ Being and Time, p. 58.
} 
what we know", to borrow loosely from Caltech Physics Professor Sean M. Carroll ${ }^{1}$, into the to-be-thought.

The disclosing-comprehending-saying power of $\lambda$ ó ${ }^{\circ} \varsigma$ is radically finite. Its ability to unearth, understand, and convey is innately limited and often prejudiced. Human being is, generally speaking, in no small measure, commonly obtuse, errant, imperfect, partial, myopic, selfish, self-seeking, egotistical, and indolent. It is not uncommon for it to repel the sweatinducing work and sacrifice authenticity often necessesitates. Indeed, when it comes to the everyday t/here-being dealing with everyday life, inauthenticity,

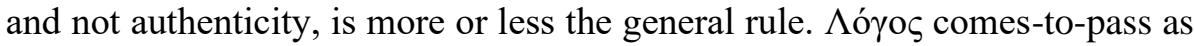
the World it never completely understands or understands clearly, an observation that corresponds with Schutz's depiction of the world of daily life as largely confused, convulted, and incoherent. Nor is the everyday $\lambda$ ó $\gamma \circ \varsigma$ especially interested in the clarity of its knowledge, in the truth of things, as Schutz also explains: the everyday person "is only partially-and we dare say exceptionally - interested in the clarity of his knowledge, i.e., in the full insight into the relations between the elements of his world and the general principles ruling those relations". The wide-awake person is generally only interested in sufficient "coherence, clarity, and consistency" to accomplish his interests at hand and allow a "reasonable chance of understanding and of being understood". ${ }^{2}$

The transcendental-horizonal perspective proposiationally discloses $\lambda$ óyos to be "an incomplete seizure of being"3 whose profound indigence preordains it to a mode of being that alienates it from itself, the World, and "others". The limitations intrinsic to its encounter with being and pavvó $\mu \varepsilon v o v$ commonly induce it to drift into free-floating, theory crafting that bury the meaning of its "to be" under a heap of metaphysical speculations about subjects and objects. The internal challenges $\lambda$ ó $\gamma$ o $\varsigma$ faces appropriating the singularity of the World appear to correspond more or less with the challenges contemporary physicists face appropriating the singularity of space-time. The phenomena are too big for us, we are too much part of them, they are too much in us, and we are not sufficiently aware to suffer them. Colombia Professor of Theoretical Physics Brian Greene speaks of the inability of everyday experience "to reveal how the universe really works,

\footnotetext{
${ }^{1}$ Sean Carroll, Sean Carroll's Mindscape, podcast audio, Episode 2: Carlo Rovelli on Quantum Mechanics, Spacetime, and Reality, 72:00, accessed 17 July 2018, 2018, https://www.stitcher.com/podcast/sean-carrolls-mindscape/e/55267398.

${ }^{2}$ Schutz, "The Stranger: An Essay in Social Psychology", p. 501.

${ }^{3}$ Richardson, Heidegger: Through Phenomenology to Thought, p. 38.
} 
and that's why a hundred years after Einstein, almost no one, not even professional physicists, feels relativity in his bones". ${ }^{1}$ The same goes with $\lambda$ ó $\gamma$ o $\varsigma$ when it comes to undergoing the phenomenon of intersubjectivity. Subjectivity is intersubjectivity. We are intersubjective through and through. The "mit", the "da", and the "sein" are everywhere a part of us. We swim in them. We breathe them. The existentials unbrokenly warp and weft through finite transcendence. The limitations intrinsic to the comprehension of being suggest the everyday person is either usually not aware enough or usually does not care enough to suffer the singularity of the World and the "is-ness" of togetherness. Intersubjectivity, as embodied in the existentials, being-with, being-with-others, and being-in-the-world, is so deeply fundamental and average, the everyday person, including the phenomenologist, or anyone for that matter, is challenged to bring its ownmost to seeing and experiencing. $\mathrm{He}$, the human person as such, t/here-being, is thrown into a mode of everydayness that includes parameters that suppress his power to experience the meaning of intersubjectivity and inabide it in daily living. The meaning of intersubjectivity persistently evades awareness. It commonly eludes "wide-awakeness", the term Schutz employs "to denote a plane of consciousness of highest tension originating in an attitude of full attention to life and its requirements" 2 . Our power to undergo the meaning of being-with, being-with-others, and being-in-the-world buckles under the depth and extendedness that distinguish their belongingness to the primal disclosedness of the human "to be". They are intrinsic to $\lambda$ ó $\gamma o \varsigma$, the event of disclosingcomprehend-saying whose power to experience them as they are and, hence, how it itself is, is overwhelmingly finite.

$c$. Death. The phenomenon of death does not generate alienation. The way one encounters its ownmost, however, has the potential to. The phenomenon of death includes the power to induce $\lambda$ ó $\gamma$ ○ or draw near transcendence. The hermeneutics of death reveals the first trajectory to be more common to the everyday mode of t/here-being. The everyday comprehension of death, the view of death common to the wideawake person in the world of daily life in light of the facticity, everyone is dying, appears to be a variable alienating $\lambda$ ó $\gamma o \varsigma$ from intersubjectivity. The phenomenon of death, rendered transcendental-horizonally, is the pre-given impending possibility of t/here-being's "absolute impossibility"3. It is the

${ }^{1}$ Briane R. Greene, The Fabric of the Cosmos: Space, Time, and the Texture of Reality (New York: Alfred A. Knopf, 2004), p. 77.

${ }^{2}$ Schutz, "On Multiple Realities", pp. 537-538.

${ }^{3}$ Heidegger, Being and Time, p. 294, 
factical possibility one day one will not be that also eminates an anxiety about migrating to nothing. Death is the "ultimate seal of $t /$ here-being's finitude", Richardson pointedly observes ${ }^{1}$, the impending annihilation of paivó $\mu \varepsilon v 0 v$, and the liquidation of the being of Da-sein's t/here ${ }^{2}$. The meaning of death contains a primordial awareness, one that pre-reflectively manifests as anxiety, $\lambda$ ó $\gamma \circ \varsigma$ will inevitably transmute to nothing.

The phenomenon of death is an existential of t/here-being. It is endemic to transcendence. T/here-being is being-toward-death. It is thrown into the World, dying. The meaning of death permeates every aspect of human being. It shapes the way t/here-being acts, thinks, and lives. It influences its decision to be. It sways in its encounter with itself, the World and "others". The hermeneutics of death shows a more or less positive correlation between an authentic appropriation of death and t/here-being's openness to paivó $\mu \varepsilon v o v$ and the possibility of inabiding the truth. Death "belongs" to life 3 , according to Viktor E. Frankl, whose existential analysis is inspired in no small measure by the transcendental-horizonal perspective ${ }^{4}$. Heidegger says the same thing differently: "Death, in the widest sense, is a phenomenon of life" . The meaning of death does not negate life. It does not "cancel" it; rather, it "is the very factor that constitutes its meaning". Death includes "a meaning-generating function" transcendence and attunes it to its unfurling as being-with, being-with-others, and being-in-the-world. It contains the power to charge $\lambda$ ó $\gamma$ os to appropriate its potentiality to be aware, free, and responsible, to come-to-pass authen-

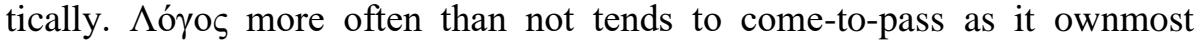
insofar as it appropriates the meaning of death. An authentic encounter with death charges it to propel itself into the truth of Da-sein and resist its pregiven drift toward its alienation from the World.

The inverse also seems to hold true. The potentiality of the encounter with death to nucleate alienation exhibits itself in the everyday tendency of

\footnotetext{
${ }^{1}$ Richardson, Heidegger: Through Phenomenology to Thought, p. 76.

${ }^{2}$ Heidegger, Being and Time, pp. 280-281.

${ }^{3}$ Viktor E. Frankl, The Doctor and the Soul: From Psychotherapy to Logotherapy, trans. Richard Winton and Clara Winton, 3rd., Expanded ed. (New York: Vintage Books, 1986), p. 67.

${ }^{4}$ George Kovacs, "The Philosophy of Death in Viktor E. Frankl", Journal of Phenomenological Psychology 13 (1982), p. 202; Joaquin Trujillo, "Frankl's Hermeneutics", Existentia 26, no. 1-2 (2016), p. 188.

${ }^{5}$ Heidegger, Being and Time, p. 290.

${ }^{6}$ Frankl, The Doctor and the Soul: From Psychotherapy to Logotherapy, p. 69.

${ }^{7}$ Kovacs, "The Philosophy of Death in Viktor E. Frankl”, p. 206.
} 
$\lambda$ ó $\gamma$ os to refute the phenomenon of death and distance itself from its to be. The everyday repulsion to the meaning of death and the possibility the negation of death is intrinsic to the ownmost of t/here-being, to Sorge, demonstrates the proclivity of human Da-sein to spurn finite transcendence, short-circuit its appropriation of the "with" and "in" dimensions of human existence, and drift into an alienation from itself, "others", and the World. ${ }^{1}$ The analysis of the everyday encounter with death deepens the appreciation of the pervasiveness (and resiliency) of alienation in the life-world. Alienation may be as common to the life-world as the rejection of death is to dying, or the "way of being in which Da-sein is towards death" 2 The meaning of death is typically fugitive to everyday Da-sein, which usually "covers up" death and "flees in the face of it" 3 . It is not uncommon for $\lambda$ ó $\gamma \circ$ to abscond, ignore, forget, or reject the meaning of death, displace it with metaphysical theses positing the continuity of subjectivity after its annihilation, and, as a consequence, distance itself from finite transcendence. Being-towards-death, the comprehension of the phenomenon thrown with $\lambda$ ó ${ }^{\circ} \varsigma$ into the World, "has the mode of evasion in the face of it-giving new explanations for it, understanding it inauthentically, and concealing it"4. The rejection of death is endemic to fallenness. Fallenness is endemic to the rejection of death. The two are positively correlated. Both phenomena speak also to the limits intrinsic to the comprehension of being, and may even

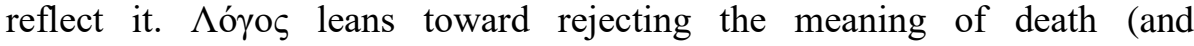
transcendence) insofar as it forgets being and owns itself over to beings, and insofar as it rejects death frees itself to lose itself in its comportment with things. "Factically, Da-sein is dying as long as it exists, but proximally and for the most part, it does so by way of falling", Heidegger shows us ${ }^{5}$.

\section{Alienation rendered being-historically}

Being-historical thinking (historical mindfulness, geschichtliches Besinnung) unfurls (extends, deepens) the hermeneutic-phenomenological understanding of alienation by underscoring the belongingness of $\lambda$ ó $\gamma o \varsigma$, hence, being-with,

\footnotetext{
${ }^{1}$ Joaquin Trujillo, "Death, Neurosis, and the Struggle-to-Meaning: A Hermeneutic Analysis of the Everyday Comprehension of Death", Existentia 27, no. 1-2 (2017).

${ }^{2}$ Heidegger, Being and Time, p. 291.

3 Ibid., pp. 295, 298.

${ }^{4}$ Ibid., pp. 296, 298.

${ }^{5}$ Ibid., p. 295.
} 
being-with-others, and being-in-the-world, to enowning, the ownmost sway of the self-clearing-concealing-withdrawing, to be-ing itself. The thesis propositionally unearthing the relationship between $\lambda$ ó $\gamma \circ \varsigma$ and enowning comprises four joined assertions. It says, as Heidegger writes in his "notes" about Contributions to Philosophy, which Emad calls some of his "most seminal, poignant, precise and enlightening reflections and comments on the central issues involved in his second major work": (1) "We experience a being because it is". (2) "A being is because be-ing holds sway". (3) "Be-ing holds sway [in human being and the World] because we endure Da-sein". (4) "We endure the Da-sein [being-t/here] insofar as the swaying enowns us. (Enowning)"2. Read within the context of Heidegger's being-historical treatises, this four-part thesis distinguishes $\lambda$ ófos, human Da-sein, as the horizon ("time-play-space") where enowning ("play") holds sway. It surmises enowning (be-ing) frees $\lambda$ ó $\gamma$ o $~$ to transform itself from within itself by gifting-refusing it the truth of being, the matter of its disclosingcomprehending-saying, and, hence, issuing-shaping within/through it the manner of its unfolding and the way it undergoes itself. This intimacy beinghistorical thinking discloses between $\lambda$ ó $\sigma \circ$ and enowning compels the hermeneutic-phenomenology of alienation also to investigate the phenomenon in relation to be-ing. It implies alienation, the originary location of which, thought transcendental-horizionally, is t/here-being's indigence, is connected to enowning's sway in transcendence.

Thinking alienation being-historically discloses the phenomenon as a part of the history (Geschichte) and destiny (Geschick) of enowning's gifting-refusing. It looks to the situatedness through-within-as $t / h e r e-b e i n g$ finds itself as a hermeneutic indicator of the ground (Grund) of alienation. It discerns history and destiny resonating in the way $\lambda$ ó $\gamma \circ \varsigma$ commonly fails to attend to itself as t/here-being, being-with, being-with-others, and being-inthe-world. Being-historical "history" is not history (Historie) understood as historicity, historiography, or chronology, an accounting of causally related events marching forward through "constant presence"3 and, hence,

\footnotetext{
${ }^{1}$ Parvis Emad, "Heidegger's Eighteen 'Notes' on Beitrage and What They Convey", in Translation and Interpretation: Learning from Beiträge, ed. Frank Schalow (Bucharest: Zeta Books, 2012), p. 41.

${ }^{2}$ Martin Heidegger, "Contributions to Philosophy: The Da-Sein and the Be-Ing (Enowning)", ibid., p. 32'. Slightly modified.

${ }^{3}$ George Kovacs, "Becoming Mindful of the History of Be-ing", Heidegger Studies 33 (2017), p, 130.
} 
"datable". It is not a mirroring of oneself in events, and, therefore, not "founded on the subject-object relationship", such that "it is objective because it is subjective", as Heidegger writes ${ }^{2}$. It is not metaphysical history. It is not a fabricated, learned, assumed, taken-for-granted, or fallen

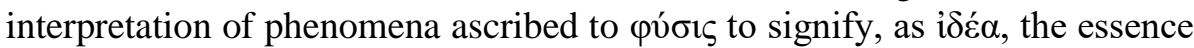
of what is. Being-historical history "is "the essential swaying of be-ing itself" 3 in the life-world and the world of daily life. It is the gifting-refusing of the truth in $\lambda$ ó $\gamma o s$, the free interplay between the attunement to being, on the one hand, and the abandonment of being (Seinsverlassenheit) or forgottenness of being (Seinsvergessenheit), on the other. It is also, perhaps, thought even more radically, the abandonment of $\mathrm{t} / \mathrm{h}$ ere-being by be-ing to a forgottenness of being.

$\Lambda$ óyos is the errancy of living through (and as) a forgottenness of being. The "clearing of be-ing is at the same time the be-ing of errancy", as Heidegger remarks in Mindfulness ${ }^{4}$, is a fundamental thesis yielded by being-

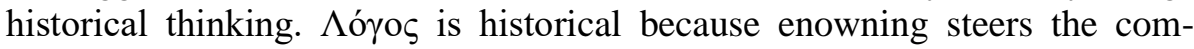
prehension of being through/from/within $\lambda$ ó ${ }_{0} \varsigma$ and shelters the truth of being within the to-be-thought. It is destiny because enowning is the ownmost of $\lambda$ ó $\gamma$ os and the sheltered contains the possibility of $\lambda$ ó $\gamma$ o $\varsigma$ coming to itself again and again in be-ing. Destiny does not signify a "'proper' way

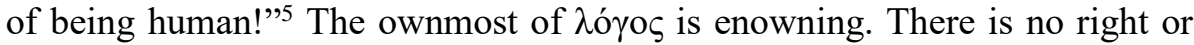
wrong about it, about the meaning of "to be". Destiny distinguishes $\lambda$ ó $\gamma \circ \varsigma$ as the struggle ingredient to be-ing, and as the struggle-to-be. It says in enowning "we have indeed" come to ourselves and "we still have not". Our completeness is found in our incompleteness and the back-and-forth interplay

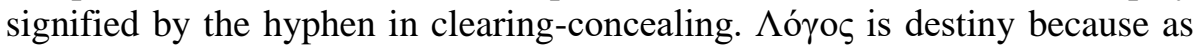
the sheltering of the concealment of truth (being) it holds, as Frank Schalow writes, "the promise of its 'recollection' in its very 'forgottenness""7.

The transcendental-horizonal perspective reveals alienation to be a mode of double-transcendence. $\Lambda$ ó ${ }^{\circ} \varsigma$ transcends beings to their being then abandons being to its absorption in beings (fallenness). The being-historical

\footnotetext{
${ }^{1}$ Martin Heidegger, "Poverty", in Heidegger, Translation, and the Task of Thinking: Essays in Honor of Parvis Emad, ed. Frank Schalow, Contributions to Phenomenology (New York: Springer, 2011), p. 3.

${ }^{2}$ Contributions to Philosophy (from Enowning), pp. 347-348.

${ }^{3}$ Ibid., p. 23; Mindfulness, p. 318.

${ }^{4}$ Mindfulness, p. 8.

5 "Contributions to Philosophy: The Da-Sein and the Be-Ing (Enowning)", p. 34

${ }^{6}$ Ibid., p. 34.

${ }^{7}$ Schalow, "Introduction", p. 30.
} 
perspective discerns the play of enowning in this doubling-back. It says being opens the way to t/here-being's abandonment of being by sheltering the

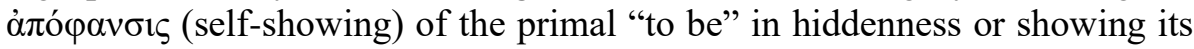
meaning as staying-away, "the clearing of the refusal" that invites the recollection of the hidden in transcendence. It says t/here-beings, together, inseparably, are the manifold "relation" of that which "surrounds them", beings-in-the-whole, one "that is exalted above the relation of subject to an object" , and that relation is enowned by be-ing. It locates alienation in the refusal of enowning to free the meaning of being-with, being-with-others, and being-in-the-world to manifest in $\lambda$ ó $\gamma \circ \varsigma$ and its abandonment of $t /$ herebeing to forgottenness. It suggests the history of $\lambda$ ó $\gamma_{0} \varsigma$ is "marked and shaped" by the "abandonment and the ensuing forgottenness (even the forgottenness of this forgottenness), as well as by the uprooting of beings from their ground in being", as Kovacs writes ${ }^{3}$.

The being-historical exposition of alienation does not exclude the transcendental-horizonal interpretation. It compliments and extends it, thinks it more radically from the perspective of be-ing. It reveals the ground of alienation to be the ab-ground (Ab-grund) of ground, the sheltering of the concealment of being ownmost to clearing (ground) "that lights up" in ground as the "hesitating refusal" of ground to show itself; ab-ground is ground self-clearing as nothing $(\lambda \dot{\eta} \theta \eta)$ or "staying-away"4. It takes one step further F.W. von Hermann's elucidation of the $D a$ (of t/here-being) as "being-disclosed-for-itself" and "being-disclosed of the world". It surmises enowning holding sway in the thrownness (Geworfenheit) of t/here-being such that it opens the way for Da-sein to overwhelmingly come-to-pass as the "self" of the "itself" of the "being-disclosed-for-itself". It reveals $\lambda$ ó $\gamma \circ$ as an inwardly aimed and inwardly absorbed t/here-being dwelling in a horizon devoid of an awareness of being because be-ing refuses to yield the

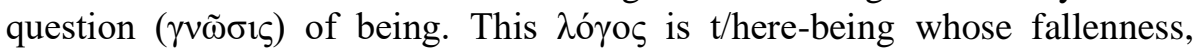
finite comprehension of being, and, maybe even, its rejection of death are given sway in transcendence by the enowned abandonment of being. It is the t/here-being enduring an estrangement from the "mit", the " $d a$ ", and the "sein" because be-ing shelters the concealment of being in transcendence.

\footnotetext{
${ }^{1}$ Heidegger, Mindfulness, p. 111.

2 "Poverty", p. 6.

${ }^{3}$ Kovacs, "Becoming Mindful of the History of Be-ing", p. 132.

${ }^{4}$ Heidegger, Contributions to Philosophy (from Enowning), p. 265.

5 Herrmann, "Dasein and Da-Sein in Being and Time and in Contributions to Philosophy (from Enowning)", p. 215.
} 
Enowning-thinking (Ereignis-Denken) alienation, projecting-opening the phenomenon within the hermeneutic course of minding the truth of being, namely, be-ing, exposes it is as an enowned mode forgottenness, on the one hand, and t/here-being's fallen absorption in beings, on the other. The "self" that ensues from this double-abandonment of being, triple if enowning not only shelters being but also abandons t/here-being to a forgottenness of being, is the mindless "self" and the subjective "self". It is $\lambda$ ó $\gamma$ os's objectification of itself as a subject. It is the machinational "self", the $\lambda$ ó $\gamma$ os absorbed in the self-stimulation of its noetic activity and impulses, has encapsulated itself within a hypothesized subject, and becomes "more and more self-conscious" as it lets itself succumb further and further to the gravity of its fallenness; "abandonment of being means that be-ing abandons beings and leaves beings to themselves and thus lets beings become objects of machination", Heidegger surmises ${ }^{2}$. It is the "self" who predominantly finds solace in "“causalities" ("if-then" and "when-then" relationships) that assure "results" . It is the calculating, planning, explaining, instrumentalizing, duplicitous, and chattering "self" whose comprehension of being enowning has freed to be seized by t/here-being's comportment with beings. It is the "self" who is existentially distanced or disjointed from its ownmost, "others", and the singularity of the World.

The enowned sway of alienation in $\lambda$ ó ${ }^{\circ} \varsigma$ is brought to view by the hermeneutic-phenomenology of language. Language is more radical than, as Gadamer says, "a mode of interpreting the world that precedes all reflective attitudes"4. The interpretation of language as a "mode" of $t /$ here-being is the first step, a transcendental-horizonal one, in exposing its relation to clearingconcealing. Language is an existential of t/here-being and equal primordial with being-with, being-with-others, and being-in-the-world. Language is the

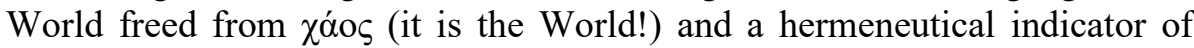
enowning's sway in transcendence, in $\lambda$ ó $\gamma$ os. Everyday language, the language of contemporary life, is a language of subjectivity, objectivity, technicity, and machination. It speaks to the failure of the wide-awake t/herebeing to live through the primal intersubjectivity of the World and points to

\footnotetext{
${ }^{1}$ George Kovacs, "Heidegger's Directives in Mindfulness for Understanding the Being-Historical Relationship of Machination and Art”, Heidegger Studies 24 (2008), p. 40.

${ }^{2}$ Heidegger, Contributions to Philosophy (from Enowning), p. 78.

${ }^{3}$ Ibid., p. 102.

4 Hans-Georg Gadamer, Philosophical Hermeneutics, trans. David E. Linge (Berkeley: University of California Press, 1977), p. 127.
} 
its destiny in relation to be-ing. It shows be-ing holding sway in factical disclosedness, in the being-of-t/here, as the forgottenness of being and the abandonment of $\mathrm{t} / \mathrm{here}$-being to its forgottenness. Be-ing is "what is truly ownmost (Wesen) to language as such", as Kovacs observes. It "comes from", is "anchored" and "grounded in", be-ing. It does not come from beings"; "the meaning swallows up the signs" munication, indication, semiotic, semiological, or pointing. It is more than a system of signs and symbols, relation between map and territory, or way that effects a simultaneity of streams of consciousness. It is historical. "Language arises from be-ing and therefore belongs to it" 3 and "is determined initially only from out of the sway of be-ing"4. It is time-play-space and the back-andforth between the clearing and forgottenness of "to be". It is enowning's principal moments (the clearing of the self-concealing-withdrawing) and the way be-ing sways in the life-world and the world of daily life. Language clears the time-play-space wherein beings manifest, leaves their being concealed in shelteredness, or shows their meaning as staying-away or withdrawing from disclosedness. It is the destiny of t/here-being. It harbors the hidden meaning of "to be".

The language of the world of daily life speaks to the historically enowned abandonment of $\lambda$ ó $\gamma$ os to a forgottenness of being. It suggests forgottenness is t/here-being's mode of to be. Everyday language, the language of the wide-awake person governed by the natural attitude and absorbed in eminently practical interests that dominate the world of daily life, is largely a language of metaphysical dualisms. It is a domain of subjects and objects, of discrete beings divested of their being, and devoid of the grammar to speak being, the "with", or the "is-ness" of togetherness. It reflects an absorption in the "top coating of meaning" of language that "sticks" to spoken and written words and "presents thought as a style, an affective value, a piece of existential mimicry" . The ability to communicate the radically average singularity of the World is not spontaneously accommodated by the vocabulary of the wide-awake person. Everyday language, thought transcendental-horizonally, may come from being-with,

1 George Kovacs, "Heidegger's Experience with Language", in Heidegger, Translation, and the Task of Thinking: Essays in Honor of Parvis Emad, ed. Frank Schalow, Contributions to Phenomenology (New York: Springer, 2011), pp. 99, 103.

${ }^{2}$ Merleau-Ponty, Phenomenology of Perception, p. 183.

${ }^{3}$ Heidegger, Contributions to Philosophy (from Enowning), p. 352.

${ }^{4}$ Mindfulness, p. 107.

${ }^{5}$ Merleau-Ponty, Phenomenology of Perception, p. 182. 
being-with-others, and being-in-the-world, but it generally does not have ready the words to liberate their self-showing. Everyday language is the language of the $\lambda$ ó $\gamma$ ○ $\varsigma$ whose ownmost has been usurped by its comportment with beings. It is metaphysical language, the language of the stock of knowledge at hand, one Schutz says comprises largely "cookery-book knowledge", "typical sequences and relations", or learned, open-ended, taken-forgranted formulas for managing life and getting things done ${ }^{1}$. It is the language and meaning of the life-world of the natural attitude. It is the lifeworld of the natural attitude. It "objectifies" human being, and "lacks the 'grammar' and the appropriate words" for speaking, thinking, and knowing being $^{2}$. It is divested of the freer attunement to being that comes with mindfulness, with thinking be-ing and "to be". It is the abode of mindlessness, the mode of human being alienated from its "to be".

The language of mindlessness is the language of technicity (Technik). It is dominated by "the technicity-bound frame of mind", as Kovacs observes. It is governed by notions of usability, function, planning, and calculation. It is machinational language. It embodies a "cultural-hermeneutic" situation, one common to contemporary life, where "the useless is regarded as good for nothing", "not worthy of attention", and "as something not to be bothered (concerned with)", the "self", the subjective "I", is idolized above

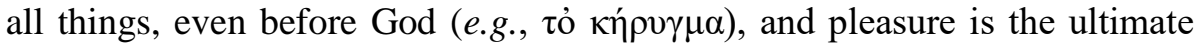
purpose of life. Heidegger calls these common features of everyday language "signs of abandonment of being" pointing to "an epoch of total lack of questioning of all things and of all machinations". They signify a human Da-sein dominated by a vocabulary of "isms", bereft of truth because of its unquestioned allegiance to relativism, and that enthusiastically succumbs to self-stimulating, metaphysical discussions of consciousness individuated as a subject (the "spirit" or "soul") migrating to another, new and better life upon death, "because everything is made of energy". The mind of mindlessness subjugates itself to talk of subjects and objects, is consumed by a motivation to accumulate things, finds its security and the meaning of itself in the heaps of objects it gathers around itself, and lays its faith in the future before the alter of technology. The technicity-framed mind, a principal feature of mindlessness, is the $\lambda$ ó $\gamma$ os enowning abandons to a forgottenness of being. It

\footnotetext{
${ }^{1}$ Alfred Schutz, "The Problem of Rationality in the Social World", Economica 10, no. 38 (1943), p. 137.

${ }^{2}$ Kovacs, "Heidegger's Experience with Language", p. 100.

3 "Heidegger's Insight into the History of Language", p. 124.

${ }^{4}$ Heidegger, Contributions to Philosophy (from Enowning), p. 86.
} 
is the mind of the "mindless zombies" who have been "taken over by machines" and their "mindless attachment to their iPhones" MIT Professor of Quantum Engineering Seth Lloyd speaks of in his answer to the posited threat of artificial intelligence. That threat, as communicated by persons such as Elon Musk and Stephen Hawking, says "we are in danger of turning over our entire society to control of some computer that will accidentally form a malign intelligence and turn us all into mindless zombies". Professor Lloyd rejoins: "there is another theory which is easily seen if you walk around the streets". It "is we already are mindless zombies who have been taken over by machines, and so it already happened". It did not require a hostile takeover from artificial intelligence ${ }^{1}$.

\section{Concluding remarks}

This article has set out to answer the question, "If the World is indeed so deeply intersubjective", as Schutz's sociology and hermeneutic phenomenology suggest, "why does the everyday person dwelling in the life-world of the natural attitude commonly fail to experience it?" That is, "Why does the common-sense person in the world of daily life generally not see or inabide the singularity of the World, and, instead, more often than not suffer his alienation from it, 'others', and, hence, itself?" The answer this study proposes: because the phenomenon of alienation is endemic to the life-world. It pervades being-in-the-world. It is always-already $t /$ here with $\mathrm{t} / \mathrm{here-being}$. $\Lambda$ óyos originarily includes its estrangement from being-with, being-withothers, and being-in-the-world. The hermeneutic-phenomenology of alienation reveals the phenomenon is endemic to paivó $\mu \varepsilon v o v$. It suggests it is intrinsic to the way intersubjectivity sways in transcendence and brings to view the meaning of phenomenon rendered by the pre-philosophical,

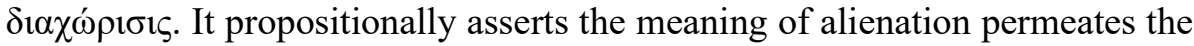
"is-ness" of togetherness. It surmises that being-with-others includes the phenomenon of being alienated from "others". T/here-beings are together in their estrangement from each other. Being-with and being-with-others includes being-distanced and being-disjointed. Being-in-the-world includes being-outside-the-world. Thought transcendental-horizonally, t/here-being is

\footnotetext{
${ }^{1}$ Seth Lloyd, 2016 Stanislaw M. Ulam Memorial Lecture Series, podcast audio, The Information Edge: Creation and Destruction in Life, the Economy, and the Universe - Part 2, https://www.santafe.edu/events/stanislaw-m-ulam-memorial-lecture-series2.
} 
thrown into the World inclined toward its estrangement from being, "others", and being-in-the-world. Not only does t/here-being often choose to distance itself phenomenally from paivó $\mu \varepsilon v o v$, as witnessed in the given tendency of $\lambda$ óyos, generally speaking, to forget being, acquiesce to fallenness, and bury the originary significance of transcendence within the everyday rejection of death, the limitations intrinsic to its comprehension of being opens the way

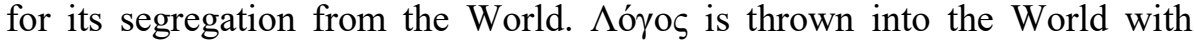
innate parameters that quash its potentiality to see and inabide the "with" and "in" of being. It is, from its onset, always-already challenged to experience the meaning of the "mit", the " $d a$ ", and the "sein".

Thought being-historically, alienation is part of the history and destiny

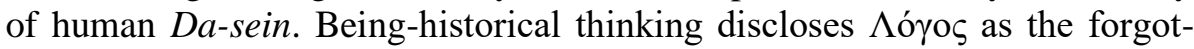
tenness of being, the abandonment to forgottenness by be-ing, and the struggle-to-be the truth of the self-clearing-concealing-withdrawing. It shows alienation to be an enowned dimension of human being. The phenomenon of alienation is freed to manifest in $\lambda$ ó $\gamma$ os by the sway of be-ing in transcendence and the enowned sequestering of the truth of being in the clearing. $\Lambda$ ó $о \varsigma$ is alienated from paivó $\mu \varepsilon v o v$ because enowning destines human $D a$ sein to an abandonment of being. Enowning shelters the truth of being, which includes the self-showing of being-with, being-with-others, and being-in-theworld, in the hiddenness cleared by its opening, in the ab-ground that belongs to ground.

Although Schutz's sociology does not address alienation explicitly, his hermeneutics connotes an interpretation of the phenomenon may be hidden within his rendition of the life-world. Schutz's sociology implies alienation is endemic to the world of daily life. The world of daily life, the life-world of the natural attitude, as he exhibits it, is experienced from its outset as an alienated world of alienated subjects intending alienated objects, including "thought-objects". It is through and through an estranged World, maybe almost as much as it is an intersubjective one. "Intersubjective" is a metaphysical (Cartesian) term more clearly rendered as, "inter-subjective". It signifies a reciprocal understanding of "betweenness" or "amongness" embodied in subjects. Betweenness and amongness, thought from the perspective contained in the word, "intersubjective", are subjective meanings denoting an "interchangeability" of standpoints and "congruency of relevances". They are constructs operating in "common-sense" thinking whereby a person (subject) assumes "the sector of the world taken for granted by me is also taken for granted by you, my individual fellow man, 
even more, that it is taken for granted by 'Us", as Schutz writes ${ }^{1}$. Subjective meanings in the world of daily life are largely intended (known) as Schutz describes them: discrete "thought-objects" learned or invented by discrete persons coming from "private" ("biographically determined") situations living a common world among discrete fellow persons ${ }^{2}$. These persons, all of them, as Schutz describes them, do not come-to-pass as the meaning language frees to manifest. They do not suffer language as the life-world nor undergo their equal primordiality with language. They encounter language as Schutz distinguishes it in the world of daily life, a system of signs, symbols, and indicators that transmits meaning among discrete subjects ${ }^{3}$. The subjective meanings of the everyday person discerned by Schutz's sociology are embedded within a forgottenness of being. They do not belong to the equal primordiality of subjects and their "paramount reality". Subjects assimilate them from their paramount reality through the instrument of language. They are "typical means for bringing about typical ends in typical situations" in an objective world of "well circumscribed objects" that is "experienced from the outset as a typical one". Typifications, as Schutz renders them, are not ontologically shared. They do not speak about persons transcending themselves and coming-to-pass as their significance. They are individually unique, "reciprocal" meanings and perspectives ${ }^{7}$ that, as Berger and Luckmann note, "hang together" as a unity ${ }^{8}$.

Now, none of this implies the subject as Schutz individuates him is ever severed from being-with, being-with-others, or being-in-the-world. The assertion, alienation is endemic to the world of daily life, signifies the way persons commonly experience their paramount reality. Nor do the preceding remarks imply Schutz thinks the subject as an object. No way! Schutz's lucid interpretations of the works of key phenomenological thinkers, including Husserl, Scheler, and Merleau-Ponty, testify to his phenomenological acumen and expertise wielding the method. "Subject", as it is discerned phenomenologically, whatever the perspective, including that of Schutz, is always consciousness as such, or consciousness understood in the broadest

\footnotetext{
${ }^{1}$ Schutz, "Common-Sense and Scientific Interpretation of Human Action", p. 8.

2 Ibid., pp. 3-4, 7-9.

${ }^{3}$ Ibid., p. 10.

${ }^{4}$ Ibid., p. 10.

5 “On Multiple Realities", p. 534.

6 "Language, Language Disturbances, and the Texture of Consciousness", p. 388.

7 "Common-Sense and Scientific Interpretation of Human Action", p. 10.

8 Berger and Luckmann, The Social Construction of Reality: A Treatise in the Sociology of Knowledge, p. 63.
} 
sense as intentionality. It is a signification of human Da-sein that largely excludes broader ontological considerations.

Alienation is a hermeneutic phenomenon. It is the meaning of the pre-

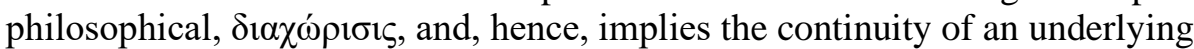
unity between separated moments whose significance is left unattended or fallow in shelteredness. Although the everyday person in the world of daily life may commonly endure his alienation from "others" and the World, he is never factically cut off from them. The "other" is ingredient to consciousness, the subject or subjectivity as such, and t/here-being. Only through selfannihilation, suicide, can t/here-being sever itself from itself, from paivó $\mu \varepsilon v o v$.

Insofar as the postulate, alienation is endemic to the world of daily life, stands on its own ground, it may suggest a modification of Schutz's baseline thesis to free his sociology to convey a more accurate reading of the reality it seeks to expose. It recommends, perhaps, we amend his start-point, "the world from the outset is not the private world of the single individual, but an intersubjective world, common to all of us", with the assertion: "that is commonly experienced as an alienated one". Not only would the retrofit bring Schutz's sociology closer in line with the hermeneutic-phenomenology of alienation (and intersubjectivity!), it may also broaden the horizons of its problematic. It may liberate his hermeneutics to render a more extended understanding of the social world by pointing to fresh matters to research. One of them could be the meanings and motivations embodied in typifications that alienate the person from his fellow persons. A good example is the typical meaning embodied in the aphorism, "Good fences make good neighbors", a statement that also underscores the chosen dimensions of alienation. The proposed amendment to Schutz's hermeneutical start-point may also invite his sociology to pay more attention to the divergences, including conflict, endemic to social phenomena and human reality.

The proposal to amend Schutz's baseline thesis may prompt considerations to revisit Husserl's transcendental-phenomenology of intersubjectivity. It suggests the thinking Husserl lays out it in his "Fifth Mediation" may be conducive to exploring the intentionally constituted determinants of the alienation from "others" commonly experienced by the common-sense person of the world of daily life, especially if the approach is executed within the interpretive (and not explanatory) context supplied by hermeneuticphenomenology. Although Schutz was correct to observe Husserl's attempt

1 Schutz, "On Multiple Realities", pp. 534, 549; Schutz and Luckmann, The Structures of the Life-World, 1, p. 4. 
to locate "the constitution of transcendental intersubjectivity" in "the operations of the consciousness of the transcendental ego" did not succeed ${ }^{1}$, an effort examined in the study preceding this one, ${ }^{2}$ his conclusion does not prescind the approach's empirical power or ability to expose phenomena related to intersubjectivity, such as alienation. In the "Fifth", Husserl identifies "constitutive association" ("pairing association," "pairing," also passive association) as a "primal form" of "passive synthesis" manifesting in the transcendental ego that automatically imputes the transcendental basis of knowing, thinking, and understanding to the intentionality it (the transcendental ego) imputes to "others" ". Forgoing speculations about the facticity of the transcendental ego or the constitution of the "other" in the transcendental sphere, thinking alienation from the perspective of passive association, a proposition favored by the notion's close correspondence with Schutz's rendition of typifications, invites us to question whether the genesis of the impulses inducing one to estrange oneself from "others" may be in some measure manifesting noetically. Intentionality could be spontaneously undergoing itself in its encounter with "others". It could be passively associating the profound indigence of $\lambda$ ó $\gamma$ os that distinguishes Da-sein as human Da-sein, and which, surmised hermeneutically, invariably resonates in consciousness, with the $\lambda$ ó $\gamma o \varsigma$ of "others". The everyday person of everyday life could be, no matter how ambiguously, primordially, or unknowingly, automatically encountering himself as hermeneutic-phenomenology surmises he commonly is, a proclivity toward mindlessness, the technicity-based, calculating, objectifying, instrumentalizing, duplicitous mind that leans on machinations to accomplish itself. He could be guarding himself against the mindlessness he senses in himself and is passively imputing to "others". T/here-being, the "mineness" of being-t/here and self-intended "apex" predator of meaning in the life-world, could be protecting itself against cannibalistic impulses it is pre-reflectively experiencing within itself and automatically associating with "others".

\footnotetext{
${ }^{1}$ Schutz, "The Problem of Transcendental Intersubjectivity in Husserl", p. 83.

2 Joaquin Trujillo, "Intersubjectivity and the Sociology of Alfred Schutz", Bulletin d'analyse phénoménologique 14, no 7 (2018).

${ }^{3}$ Husserl, "Fifth Meditation", pp. 112-119.
} 


\section{References}

Berger, Peter L., and Thomas Luckmann. The Social Construction of Reality: A Treatise in the Sociology of Knowledge. New York: Doubleday, 1967.

Berger, Peter L., and Stanley Pullberg. "Reification and the Sociological Critique of Consciousness". History and Theory 4, no. 2 (1965): 196-211.

Carroll, Sean. Sean Carroll's Mindscape. Podcast audio. Episode 2: Carlo Rovelli on Quantum Mechanics, Spacetime, and Reality 72:00. Accessed 17 July 2018, 2018. https://www.stitcher.com/podcast/sean-carrolls-mindscape/e/55267398.

Emad, Parvis. "Heidegger's Eighteen 'Notes' on Beitrage and What They Convey". Translated by Parvis Emad. In Translation and Interpretation: Learning from Beiträge, edited by Frank Schalow, 41-59. Bucharest: Zeta Books, 2012.

-. "On the Inception of Being-Historical Thinking and Its Unfolding as Mindfulness". Heidegger Studies 16 (2000): 55-71.

-. On the Way to Heidegger's Contributions to Philosophy. Madison: University of Wisconsin Press, 2007.

Frankl, Viktor E. The Doctor and the Soul: From Psychotherapy to Logotherapy. Translated by Richard Winton and Clara Winton. 3rd., Expanded ed. New York: Vintage Books, 1986.

Gadamer, Hans-Georg. Philosophical Hermeneutics. Translated by David E. Linge. Berkeley: University of California Press, 1977.

Greene, Briane R. The Fabric of the Cosmos: Space, Time, and the Texture of Reality. New York: Alfred A. Knopf, 2004.

Gurwitsch, Aron. "Introduction". In Collected Papers III: Studies in Phenomenological Philosophy, edited by I. Schutz, xi-xxxi. The Hague: Martinus Nijhoff, 1966.

Heidegger, Martin. "As When on a Holiday". Translated by Keith Hoeller. In Elucidations of Hölderlin's Poetry, edited by Keith Hoeller, 67-99. Amherst: Humanity Books, 2000.

- Being and Time. Translated by John Macquarrie and Edward Robinson. New York: Harper \& Row, Publishers, 1962.

-. Contributions to Philosophy (from Enowning). Translated by Parvis Emad and Kenneth Maly. Bloomington: Indiana University Press, 1999.

- "Contributions to Philosophy: The Da-Sein and the Be-Ing (Enowning)". Translated by Parvis Emad. In Translation and Interpretation: Learning from Beiträge, edited by Frank Schalow, 29-39. Bucharest: Zeta Books, 2012.

-. "Hölderin and the Essence of Poetry". Translated by Keith Hoeller. In Elucidations of Hölderlin's Poetry, edited by Keith Hoeller, 51-65. Amherst: Humanity Books, 2000.

- Mindfulness. Translated by Parvis Emad and Thomas Kalary. London: Continuum International Publishing Group, 2006.

-. "Poverty". Translated by Thomas Kalary and Frank Schalow. In Heidegger, Translation, and the Task of Thinking: Essays in Honor of Parvis Emad, edited 
by Frank Schalow. Contributions to Phenomenology, 3-10. New York: Springer, 2011.

-. "The Origin of the Work of Art". Translated by Albert Hofstadter. In Poetry, Language, Thought, edited by Albert Hofstadter, 15-86. New York: Perennial Classics, 2001.

Herrmann, Friedrich-Wilhelm von. "Dasein and Da-Sein in Being and Time and in Contributions to Philosophy (from Enowning)". Translated by Bernhard Radloff. In Heidegger, Translation, and the Task of Thinking: Essays in Honor of Parvis Emad, edited by Frank Schalow. Contributions to Phenomenology, 213-24. New York: Springer, 2011.

Husserl, Edmund. "Fifth Meditation". Translated by Dorion Cairns. In Cartesian Mediations: An Introduction to Phenomenology, 89-157. Boston: Kluwer Academic Publishers, 1999.

Kalary, Thomas, and Frank Schalow. "Attunement, Discourse, and the Onefold of Hermeneutic Phenomenology: Recent Heidegger-Literature and a New Translation of His Work in Critical Perspective". Heidegger Studies 27 (2011): 199-210.

Kovacs, George. "Becoming Mindful of the History of Be-ing". Heidegger Studies 33 (2017): 129-43.

-. "Heidegger's Directives in Mindfulness for Understanding the Be-ing-Historical Relationship of Machination and Art". Heidegger Studies 24 (2008): 39-60.

-. "Heidegger's Experience with Language". In Heidegger, Translation, and the Task of Thinking: Essays in Honor of Parvis Emad, edited by Frank Schalow. Contributions to Phenomenology, 95-109. New York: Springer, 2011.

-. "Heidegger's Insight into the History of Language". Heidegger Studies 29 (2013): 121-32.

—. "The Idea of Hermeneutics in Heidegger". Existentia 10, no. 1-4 (2000): 41-50.

-. "The Philosophy of Death in Viktor E. Frankl". Journal of Phenomenological Psychology 13 (1982): 197-209.

-. The Question of God in Heidegger's Phenomenology. Evanston: Northwestern University Press, 1990.

Lloyd, Seth. 2016 Stanislaw M. Ulam Memorial Lecture Series. Podcast audio. The Information Edge: Creation and Destruction in Life, the Economy, and the Universe - Part 2. https://www.santafe.edu/events/stanislaw-m-ulam-memoriallecture-series-2.

Merleau-Ponty, Maurice. Phenomenology of Perception. Translated by Colin Smith. London: Routledge \& Kegan Paul, 1962.

Richardson, S.J., William J. Heidegger: Through Phenomenology to Thought. 2nd ed. The Hague: Martinus Nijhoff, 1967.

Schalow, Frank. "Introduction". In Heidegger, Translation, and the Task of Thinking: Essays in Honor of Parvis Emad, edited by Frank Schalow. Contributions to Phenomenology, 11-47. New York: Springer, 2011.

Schutz, Alfred. "Choosing among Projects of Action". Philosophy and Phenomenological Research 12, no. 2 (December 1951): 161-84. 
-. "Common-Sense and Scientific Interpretation of Human Action". Philosophy and Phenomenological Research 14, no. 1 (September 1953): 1-38.

-. "Language, Language Disturbances, and the Texture of Consciousness". Social Research 17, no. 3 (September 1950): 365-94.

—. "Making Music Together: A Study in Social Relationship". Social Research 18, no. 1 (March 1951): 76-97.

-. "On Multiple Realities". Philosophy and Phenomenological Research 5, no. 4 (June 1945): 533-76.

-. The Phenomenology of the Social World. Translated by George Walsh and Frederick Lehnert. Evanston: Northwest University Press, 1967.

—. "The Problem of Rationality in the Social World". Economica 10, no. 38 (May 1943): 130-49.

-. "The Problem of Transcendental Intersubjectivity in Husserl". In Collected Papers III: Studies in Phenomenological Philosophy, edited by I. Schutz, 51-83. The Hague: Martinus Nijhoff, 1966.

—. "The Stranger: An Essay in Social Psychology". American Journal of Sociology 49, no. 6 (May 1944): 499-507.

—. "Symbol, Reality and Society". In Symbols and Society: Fourteenth Symposium on Science, Philosophy, and Religion, edited by Lyman Bryson, Louis Finkelstein, Hudson Hoagland and R.M. MacIver. New York: Harper and Brothers, 1955.

—. "Tiresias, or Our Knowledge of Future Events". Social Research 26, no. 1 (1959): 71-89.

Schutz, Alfred, and Thomas Luckmann. The Structures of the Life-World. Translated by Richard M. Zaner and David J. Parent. Vol. 2, Evanston: Northwestern University Press, 1989.

- The Structures of the Life-World. Translated by Richard M. Zaner and Jr. H. Tristram Engelhardt. Vol. 1, Evanston: Northwestern University Press, 1995.

Simmel, George. Conflict and the Web of Group-Affiliations. Translated by Kurt H. Wolff and Reinhard Bendix. New York: The Free Press, 1955.

Trujillo, Joaquin. “Frankl's Hermeneutics”. Existentia 26, no. 1-2 (2016): 187-220.

—. "Death, Neurosis, and the Struggle-to-Meaning: A Hermeneutic Analysis of the Everyday Comprehension of Death". Existentia 27, no. 1-2 (2017): 193-230.

-, "Intersubjectivity and the Sociology of Alfred Schutz", Bulletin d'analyse phénoménologique 14, no 7 (2018). 